\title{
ARAŞTIRMA / RESEARCH \\ Gestasyonel diabetes mellitus tanısında bir biyobelirteç olarak serum prokalsitonin düzeyi
}

Serum procalcitonin levels as a biomarker for diagnosis gestational diabetes mellitus

Süleyman Baldane, Süleyman Hilmi İpekci, Ayşegül Kebapcılar, Sedat Abuşoğlu, Bahadır Öztürk, Ali Ünlü, Çetin Çelik, Levent Kebapcilar

Selçuk Üniversitesi Tıp Fakültesi; İç Hastalıkları Anabilim Dalı, Endokrinoloji ve Metabolizma Hastalıkları Bilim Dalı, Konya, Turkey

\begin{abstract}
Purpose: The aim of this study was set as to compare procalcitonin levels of gestational diabetes mellitus patients and healthy pregnant individuals and evaluate link between serum procalcitonin concentration and metabolic parameters of gestational diabetes mellitus. Materials and Methods: 142 pregnant individual who consulted to Endocrinology Division were taken to the study. According to the oral glucose tolerance test results, 57 were diagnosed gestational diabetes mellitus, and 85 healthy pregnant were included in the control group. For the serum analysis, samples were obtained after overnight fasting and between 7:00 AM and 8:00 AM.

Results: In the gestational diabetes mellitus group serum procalcitonin levels was found significantly higher than control group. A positive correlation was found between serum procalcitonin levels and fasting glucose and oral glucose tolerance test 60 . minute glucose levels.

Conclusion: Our results shown that levels of serum procalcitonin in gestational diabetic mellitus were significantly higher than healthy pregnancies for the first time. This result supports the knowledge that chronic lowgrade inflammation plays an important role in the pathogenesis of gestational diabetes mellitus. Procalcitonin level may be considered as a new biomarker for chronic low-grade inflammation in patients with gestational diabetes mellitus
\end{abstract}

Key words: Gestational diabetes mellitus, procalcitonin, inflammation

\section{Öz}

Amaç: Bu çalışmanın amacı gestasyonel diabetes mellitus hastalarında ve sağlıklı gebelerde serum prokalsitonin düzeylerini karşılaştırmak ve prokalsitonin düzeyinin diğer metabolik parametreler ile ilişkisini değerlendirilmesidir.

Gereç ve Yöntem: Endokrinoloji Bilim Dalı polikliniğine başvuran 142 gebe çalışmaya dahil edildi. Oral glukoz tolerans testi sonuçlarına göre 57 gebeye gestasyonel diabet mellitus tanısı konuldu. 85 sağlıklı gebe ise kontrol grubuna dahil edildi. Serum analizi için tüm kan örnekleri bir gecelik açlık sonrası oral glukoz tolerans testi başlangıcında sabah 7:00 ve 8:00 saatleri arasında alındı.

Bulgular: Gestasyonel diabet mellitus grubunda serum prokalsitonin düzeyleri kontrol grubuna göre anlamlı olarak yüksek bulundu. Serum prokalsitonin düzeyi ile açlik glukozu ve oral glukoz tolerans testi 60. dakika glukoz düzeyleri arasında anlamlı pozitif korelasyon bulundu.

Sonuç: Bu çalışmada gestasyonel diabet mellitus'lu gebelerde serum prokalsitonin düzeylerinin sağlıklı gebelere göre anlamlı olarak yüksek olduğu ilk kez gösterilmiştir. $\mathrm{Bu}$ sonuç kronik düşük-dereceli inflamasyonun gestasyonel diabet mellitus patogenezinde önemli role sahip olduğu bilgisini desteklemektedir. Prokalsitonin düzeyi gestasyonel diabet mellitus hastalarında kronik düşük-dereceli inflamasyonun yeni bir biyobelirteci olarak düşünülebilir.

Anahtar kelimeler: Gestasyonel diabetes mellitus, prokalsitonin, inflamasyon

\section{GİRİŞ}

Gestasyonel diabetes mellitus (GDM); gebelik esnasında başlayan veya ilk kez gebelikte fark edilen değişen derecelerde glukoz intoleransı olarak tanımlanır ${ }^{1}$. GDM tüm gebeliklerin yaklaş1k \% $\%$ 'inde görülür ve ileriki yaşamda tip 2 diyabet gelişimi için oldukça güçlü bir risk faktörüdür ${ }^{2}$. GDM 
gelişiminden sorumlu tutulan başlıca patofizyolojik mekanizmalardan biri, tip 2 diyabette olduğu gibi, kronik düşük-dereceli inflamasyondur ${ }^{3}$. Son y1llarda GDM hastalarında visfatin, omentin gibi yeni sitokinlerin kronik düşük-dereceli inflamasyona katkısını değerlendiren önemli çalışmalar yayınlanmıştır ${ }^{4,5}$ ancak prokalsitoninin (PCT) bu duruma olası katkısı daha önce değerlendirilmemiştir.

PCT, 116 aminoasitten oluşan, hormonal aktiviteye sahip olmayan, kalsitonin prekürsörü bir polipeptiddir. PCT enfeksiyon ve ciddi sistemik inflamasyonu gösteren en iyi biyobelirteç olarak bilinmektedir. Dahası in vitro çalışmalarda aktive olmuş makrofajların stimülasyonu ile adipoz doku parankim hücrelerinin PCT sekrete etme yeteneğine sahip olduğu gösterilmiştir ve bu durum PCT'yi kronik düşük-dereceli inflamasyonun potansiyel bir biyobelirteci haline getirmiştir ${ }^{6,7}$.

$\mathrm{Bu}$ çalışmanın amacı GDM’li ve sağlıklı gebelerde serum PCT düzeylerini karşılaştırmak ve PCT düzeyinin diğer metabolik parametreler ile ilişkisini değerlendirmek olarak belirlendi.

\section{GEREÇ VE YÖNTEM}

\section{Çalışma popülasyonu}

$\mathrm{Bu}$ çalışma bir kesitsel vaka-kontrol çalışmasıdır. Çalışma, Tıp Fakültesi Etik Kurulu'nun 21/03/2013 tarihli ve 2013/69 sayılı izni ile gerçekleștirildi ve çalışmaya dahil edilen tüm gebe bireylerden aydınlatılmış onam formu alındı. Endokrinoloji Bilim Dalı polikliniğine Mayıs 2013 ile Mayıs 2014 tarihleri arasında başvuran 161 gebe çalışmaya alındı. Sigara ve alkol kullanımı, preeklampsi, eklampsi, pregestasyonel diyabet, malignite, kronik inflamatuar veya otoimmün hastalı ve akut veya kronik enfeksiyon varlığ dişlama kriterleri olarak belirlendi. 19 hasta dışlama kriterlerinin varlığ1 nedeniyle çalışmadan çıkarıldı ve 142 hasta ile çalışma tamamlandi.

\section{Demografik veriler ve GDM tanı ölçütleri}

Tüm gebelerin yaşı, gebelik haftası, boy, kilo, beden kitle indeksi (BKI), bel çevresi, kalça çevresi ve kan basinc1 ölçümleri kaydedildi. Sigara ve alkol kullanımı kaydedildi. Çalışmaya alınan tüm gebelere 24-28. gebelik haftaları arasında 50 gram oral glukoz tolerans testi (OGTT) ile GDM taraması yapıldı. 50 gram OGTT 1.saat glukoz düzeyleri $140 \mathrm{mg} / \mathrm{dl}$ ve üstünde olan hastalara tanı doğrulama testi olarak 100 gram OGTT testi yapıldı. GDM tanisı Carpenter and Coustan ${ }^{8}$ kriterlerine uygun olarak 100 gram OGT'T testinde iki ve daha fazla anormal değere sahip hastalara konuldu.

\section{Laboratuar ölçüm yöntemleri}

Serum analizi için tüm kan örnekleri bir gecelik açlık sonrası OGTT başlangıcında sabah 07-08 saatleri arasında alındı. PCT serum düzeyi spesifik immunoluminometrik assay ile ölçüldü (BRAHMS PCT sensitive LIA; Hennigsdorf, Germany). Açlık insülin ve glukoz düzeyleri sirasiyla hexokinase (Abbott Architect), immuno kemiluminesans (Roche E170) yöntemleri ile ölçüldü. İnsülin direnci belirteci olarak kullanılan HOMA-IR (Homeostasis Model Assesment Of Insulin Resistance) aşağıda verilen formüle göre hesapland19: [(açlık insülin, $\mathrm{mIU} / \mathrm{ml}) \times($ açlık glukoz, mg/dl $) / 405]$.

\section{İstatistiksel analiz}

Verilerin istatistiksel analizinde SPSS versiyon 20.0 programı kullanıldı. Parametrik verilerde iki grup ortalama karşılaştırması Student's t testi ile, nonparametrik verilerde iki grup ortanca karşılaştırılması Mann Whitney U testi ile yapıldı. Normal dağılan veriler ortalama \pm standart sapma, normal dağılmayan veriler ortanca (minumum-maksimum) olarak gösterildi. PCT ile diğer parametreler arasındaki korelasyon analizi spearman korelasyon testi ile yapıldı. p değeri $<0.05$ ise anlamlı olarak kabul edildi.

\section{BULGULAR}

OGTT sonuçlarına göre 57 gebeye GDM tanısı konuldu. 85 sağlıklı gebe ise kontrol grubuna dahil edildi. GDM ve kontrol grubuna ait gebelerin tüm klinik ve laboratuar özellikleri ve bu özelliklerin gruplar arasında istatistiksel karşılaştırılma sonuçları Tablo 1'de verildi.

Gruplar arasında gebelik haftası, BKİ, bel çevresi, kalça çevresi ve kan basıncı açısından farklılık izlenmedi. GDM grubunda yaş anlamlı olarak yüksek bulundu (Tablo 1). GDM grubunda açlık insülin, açlık glukozu ve PCT düzeyleri anlamlı olarak yüksek bulundu (sırasıyla p değerleri: 0.014, < 0.001, 0.009). HOMA-IR, beyaz küre ve nötrofil değerleri GDM grubunda daha yüksek bulunmasına rağmen gruplar arasında istatistiksel anlamlı fark 
görülmedi. PCT düzeyi ile açlık glukozu ve OGTT 60. dakika glukoz düzeyleri arasında pozitif korelasyon bulundu (sırasiyla $\mathrm{r}=0.277, \mathrm{p}=0.001$ ve $\mathrm{r}=0.298, \mathrm{p}<0.001$ ) (şekil 1, şekil 2). PCT ile HOMA-IR ve açlık insülin düzeyleri arasında korelasyon izlenmedi.

\section{TARTIŞMA}

$\mathrm{Bu}$ çalışmada serum PCT düzeyinin GDM hastalarında sağlıklı gebelere göre anlamlı olarak yüksek olduğu gösterildi. Ayrıca PCT düzeyi ile açlık glukozu ve OGTT 60. dakika glukoz düzeyleri arasında anlamlı pozitif korelasyon varlığı gösterildi. PCT ile HOMA-IR, açlık insülin ve BKİ değerleri arasında ise anlamlı korelasyon izlenmedi. Kronik düşük-dereceli inflamasyon GDM gelişiminde önemli role sahip patofizyolojik mekanizmalardan biridir $^{3}$. GDM'li hastalarda gebelik esnasinda ve sonrasinda C-reaktif protein (CRP), interlökin-6 (IL6) ve tümor nekrozis faktör alfa (TNF-a) gibi proinflamatuar sitokin düzeylerinin arttığ gösterilmiştir ${ }^{10,11}$. $\mathrm{Bu}$ proinflamatuar sitokinlerin insülin sinyal sistemini aksatarak insülin direnci ve glukoz metabolizma bozukluğuna neden olduğu düşünülmektedir ${ }^{10,11}$.

Deneysel çalışma verileri PCT’nin sepsis veya sistemik enfeksiyon yokluğunda non-enfeksiyöz inflamasyon biyobelirteci olabileceğini destekleyen bulgular içermektedir ${ }^{6,7}$. İnsan yăg dokusu depolarının, nöroendokrin olmayan kalsitonin mRNA ekspresyonun majör alanı olduğu belirlenmiştir ${ }^{6,7}$ ve adipositlerden in vitro PCT sekresyonu aktive makrofajlar tarafindan stimüle edilmektedir ${ }^{7}$ Aynı senaryo makrofaj aktivasyonunun artığ1 in vivo koşullarda gerçekleşebilir. Ayrıca deneysel çalışmalar PCT’nin kalsitonin reseptör kompleksi üzerinden etkili olarak vasküler tonus, insülin direnci ve pankreas $\beta$ hücrelerinden insülin sekresyonu üzerinde etkisi olduğunu göstermiştir ${ }^{6}$.

Tablo 1. GDM ve kontrol grubuna ait klinik ve laboratuar bulgularının karşılaştırılması

\begin{tabular}{|l|c|c|c|}
\hline Parametre & GDM (n = 57) & Kontrol (n = 85) & p \\
\hline Yaş (yll) & $31.1 \pm 5.3$ & $28.1 \pm 4.6$ & $<0.001$ \\
\hline BKI (kg/m²) & $30.48(18.96-41.15)$ & $28.35(20.70-43.97)$ & 0.208 \\
\hline Bel çevresi (cm) & $101.3 \pm 9.4$ & $95 \pm 9.5$ & 0.914 \\
\hline Kalça çevresi (cm) & $111.2 \pm 8.0$ & $107.7 \pm 9.7$ & 0.289 \\
\hline Sistolik KB (mmHg) & $112.2 \pm 14.1$ & $110.3 \pm 12.4$ & 0.530 \\
\hline Diastolik KB (mmHg) & $72.1 \pm 9.1$ & $66.3 \pm 8.4$ & 0.604 \\
\hline Gebelik haftası (hafta) & $26.26 \pm 4.27$ & $25.85 \pm 2.16$ & 0.128 \\
\hline Prokalsitonin & $0.038(0.01-0.11)$ & $0.010(0.01-0.08)$ & 0.009 \\
\hline Açlik glukozu (mg/dl) & $94 \pm 15$ & $79 \pm 5$ & 0.010 \\
\hline İnsülin (mIU/ml) & $9.32(1-31.73)$ & $7.29(1-34.90)$ & 0.014 \\
\hline HOMA-IR & $2.24(0.19-5.87)$ & $1.76(0.17-5.69)$ & 0.082 \\
\hline Beyaz küre (x1000/mm3) & $10.31 \pm 2.17$ & $10.02 \pm 2.38$ & 0.400 \\
\hline Nötrofil (x1000/mm3) & $7.77 \pm 2.05$ & $7.38 \pm 2.03$ & 0.210 \\
\hline Hemoglobin (g/dl) & $12.55 \pm 1.07$ & $12.47 \pm 1.09$ & 0.624 \\
\hline Platelet (x1000/mm3) & $232.4 \pm 57.5$ & $221.0 \pm 44.9$ & 0.155 \\
\hline OGTT 60. dk glukoz (mg/dl) & $191 \pm 29$ & $141 \pm 24$ & $<0.001$ \\
\hline OGTT 120. dk glukoz (mg/dl) & $165 \pm 28$ & $118 \pm 22$ & $<0.001$ \\
\hline OGTT 180. dk glukoz (mg/dl) & $122(36-226)$ & $95(52-139)$ & $<0.001$ \\
\hline
\end{tabular}

GDM: gestasyonel diabetes mellitus, BKİ: beden kitle indeksi, KB: kan basınc1, HOMA-IR: homeostasis model assessment insulin resistance index, OGTT: oral glukoz tolerans testi 


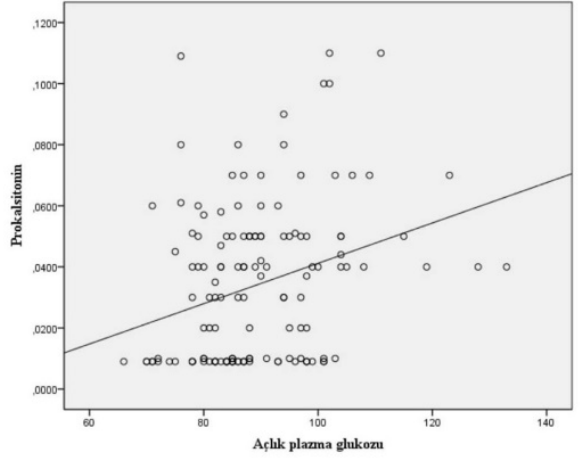

Şekil 1. PCT ve açlık glukozu arasındaki korelasyon

PCT’nin kronik düşük-dereceli inflamasyonun değerlendirilmesinde kullanımı ile ilgili klinik çalışmalar da mevcuttur. Puder ve arkadaşları tarafindan polikistik over sendromu olan kadınlarda PCT düzeyi ile santral yağlanma arasında ilişki rapor edilmiştir ${ }^{12}$ ve yağ dokusunun inflamatuar aktivitesini gösteren yeni bir biyobelirteç olabileceği düşünülmüştür. Abbasi ve arkadaşları tarafından yapılan kesitsel çalışmada genel popülasyonda hem erkeklerde hem de kadınlarda artmış PCT düzeyinin insülin direnci ve metabolik sendrom komponentleri ile ilişkili olduğu gösterilmiştir ${ }^{13}$. Bu çalışmada PCT ile insülin direnci ve metabolik sendrom komponentleri arasındaki ilişki BKI için düzeltme yapıldıktan sonra azalmıştır ve bu durumun plazma PCT düzeyinin adipoz doku kitlesinden çok adipoz doku disfonksiyonu ile ilişkili olması ile ilgili olduğu düşünülmüştür. BKİ ile kısmi ilișkisi nedeniyle PCT adiposit disfonksiyonu ve/veya kronik düşükdereceli inflamasyonun yeni bir biyobelirteci olarak düşünülebilir. Abbasi ve arkadaşları bir sonraki prospektif çalışmalarında genel popülasyonda PCT düzeyinin tip 2 diyabet gelişimi için bağımsız bir prediktör olduğunu rapor etmişlerdir ${ }^{14}$. Van Ree ve arkadaşları renal transplant hastalarında PCT'nin geç dönem greft yetmezliğini öngörmede güçlü ve bağımsız bir prediktör olduğunu bildirmişlerdir ve renal transplant hastalarında PCT'nin nonenfeksiyöz kronik düşük-dereceli inflamasyon değerlendirmesi için kullanışlı bir biyobelirteç olabileceğini bildirmişlerdir ${ }^{15}$. Yakın zamanda yapılan bir diğer çalışmada Wan ve arkadaşları PCT düzeyinin diyabetik nefropatisi olan hastalarda, mikroalbüminürisi olan diyabet hastaları, nefropatisi olmayan diyabet hastaları ve sağlıklı kontrol grubuna

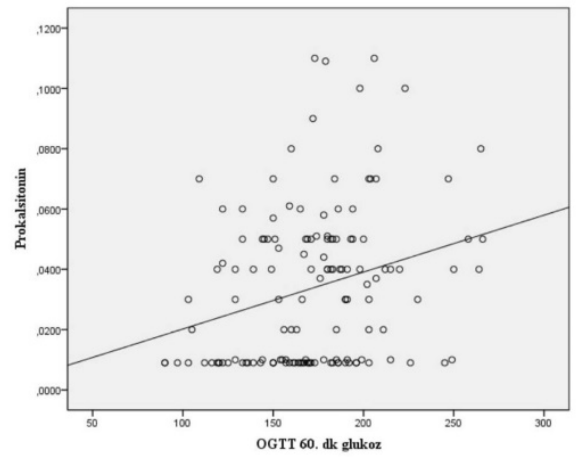

Şekil 2. PCT ve OGTT 60. dakika glukoz düzeyleri arasındaki korelasyon

göre anlamlı olarak yüksek olduğunu rapor etmişlerdir ve kronik düşük-dereceli inflamasyon ve renal hasar ilişkisine dikkat çekmişlerdirr ${ }^{16}$. Kesitsel bir çalışma olması, kısıtlı hasta sayısı ile yapılması, perinatal sonuçların ve hsCRP, TNF-a ve IL-6 gibi major proinflamatuar sitokinlerin PCT ile ilisskisinin değerlendirilmemiş olması bu çalışmanın başlıca k1sıtlayıcı özellikleridir.

Sonuç olarak GDM patofizyolojisinde kalsitonin ilişkili sistemlerin potansiyel rolünü ve PCT'nin GDM hastalarında kronik düşük-dereceli inflamasyon biyobelirteci olarak tanısal kullanımının prospektif, geniş katılımlı çalışmalarla değerlendirmenin uygun olacağını düşünmekteyiz.

\section{KAYNAKLAR}

1. Buchanan TA, Xiang AH, Page KA. Gestational diabetes mellitus: risks and management during and after pregnancy. Nat Rev Endocrinol. 2012;8:639-49.

2. Lauenborg J, Hansen T, Jensen DM, Vestergaard H, Mølsted-Pedersen L, Hornnes $\mathrm{P}$ et al. Increasing incidence of diabetes after gestational diabetes: a long-term follow-up in a Danish population. Diabetes Care. 2004;27:1194-9.

3. Lekva T, Norwitz ER, Aukrust P, Ueland T. Impact of systemic inflammation on the progression of gestational diabetes mellitus. Curr Diab Rep. 2016;16:26.

4. Rezvan N, Hosseinzadeh-Attar MJ, Masoudkabir F, Moini A, Janani L, Mazaherioun M. Serum visfatin concentrations in gestational diabetes mellitus and normal pregnancy. Arch Gynecol Obstet. 2012;285:1257-62.

5. Aktas G, Alcelik A, Ozlu T, Tosun M, Tekce BK, Savli $\mathrm{H}$ et al. Association between omentin levels and 
insulin resistance in pregnancy. Exp Clin Endocrinol Diabetes. 2014;122:163-6.

6. Linscheid P, Seboek D, Nylen ES, Langer I, Schlatter $\mathrm{M}$, Becker $\mathrm{KL}$ et al. In vitro and in vivo calcitonin I gene expression in parenchymal cells: a novel product of human adipose tissue. Endocrinology. 2003;144:5578-84.

7. Linscheid P, Seboek D, Schaer DJ, Zulewski H, Keller U, Müller B. Expression and secretion of procalcitonin and calcitonin generelated peptide by adherent monocytes and by macrophage-activated adipocytes. Crit Care Med. 2004;32:1715-21.

8. Coustan DR, Carpenter MW. The diagnosis of gestational diabetes. Diabetes Care. 1998;21:5-8.

9. Wallace TM, Levy JC, Matthews DR. Use and abuse of HOMA modeling. Diabetes Care. 2004;27:148795

10. McLachlan KA, O'Neal D, Jenkins A, Alford FP. Do adiponectin, TNF alpha, leptin and CRP relate to insulin resistance in pregnancy? Studies in women with and without gestational diabetes, during and after pregnancy. Diabetes Metab Res Rev. 2006;22:131-8

11. Kuzmicki M, Telejko B, Zonenberg A, Szamatowicz J, Kretowski A, Nikolajuk A, et al. Circulating proand anti-inflammatory cytokines in Polish women with gestational diabetes. Horm Metab Res. 2008;40:556-60.

12. Puder JJ, Varga S, Kraenzlin M, De Geyter C, Keller U, Müller B. Central fat excess in polycystic ovary syndrome: relation to low-grade inflammation and insulin resistance. J Clin Endocrinol Metab. 2005;90:6014-21.

13. Abbasi A, Corpeleijn E, Postmus D, Gansevoort RT, de Jong PE, Gans RO et al. Plasma procalcitonin is associated with obesity, insulin resistance, and the metabolic syndrome. J Clin Endocrinol Metab. 2010;95:26-31.

14. Abbasi A, Corpeleijn E, Postmus D, Gansevoort RT, de Jong PE, Gans RO et al. Plasma procalcitonin and risk of type 2 diabetes in the general population. Diabetologia. 2011;54:2463-5.

15. van Ree RM, de Vries AP, Oterdoom LH, Seelen MA, Gansevoort RT, Schouten JP et al. Plasma procalcitonin is an independent predictor of graft failure late after renal transplantation. Transplantation. 2009;88:279-87.

16. Wan ZM, Chen WY, Lu ML, Zhou HT, Gao YL, Zhang $\mathrm{C}$ et al. Higher procalcitonin level in diabetic nephropathy patients compared with healthy volunteers. Sichuan Da Xue Xue Bao Yi Xue Ban. 2014;45:442-6. 